\title{
The Niger Delta Amnesty - An Amnesty in Search of a Legal Legitimacy
}

\author{
Eje Adakole Odike \\ Senior Lecturer and Dean, Faculty of Law, National Open University of Nigeria, Abuja, Nigeria
}

\begin{abstract}
On the $6^{\text {th }}$ of August 2009, the former President of Nigeria, Umaru Musa Yar'adua, (now late), declared amnesty for militants of the Niger Delta region of Nigeria (here in after called "the Niger Delta Amnesty") based on the recommendation of the Presidential Technical Committee on the Niger Delta. The paper uses doctrinaire approach to appraise the Niger Delta Amnesty touted as a "home grown" amnesty. Based on statutes, case laws, opinions of legal text writers, newspaper comments and internet sources, it disappointedly finds out that the Niger Delta Amnesty, unlike many other amnesties, is not anchor on any known Nigeria law. It is the contention of the paper that such an important public proclamation should be anchored on a constitutional provision or an Act of the National Assembly. In the absence of such a legal validity, the paper recommends that the President of Nigeria should, as a matter of public importance and urgency, package the Niger Delta Amnesty Program in form of Executive bill and forward the same to the National Assembly for enactment as a law. This, the paper believes will guarantee its longevity and secure it from being used as a political tool.
\end{abstract}

Keywords: amnesty, pardon, clemency, militants, militancy, impunity, legitimacy

DOI: $10.7176 / \mathrm{JLPG} / 101-06$

Publication date:September $30^{\text {th }} 2020$

\section{Introduction}

It is better we preface the paper with a brief explanation of the keywords used herein. In this paper:

"Amnesty" means, a general pardon granted by the government to a group (class) of persons who are subject to trial but have not been tried or convicted.

"Pardon" means, the act of officially nullifying punishment. A pardon maybe general or specific in nature i.e. ordinary pardon. ${ }^{1}$

"Clemency" means, mercy granted by the President in the exercise of a conferred power to pardon a criminal by commuting his or her criminal sentence. ${ }^{2}$

"Militants" means, a group of persons that uses force or strong measure, with or without violence in order to achieve an avowed aim; especially as it relates to socio-political causes.

"Militancy" means, the act of vigorously or combatively or aggressively fighting for a cause.

"Impunity" means, freedom or exemption from punishment from the injurious consequences of an action.

"Legitimacy" means, conforming to law.

The Niger Delta area of Nigeria, hereinafter referred to as "The Niger Delta region" is located in the Gulf of Guinea. It is bounded in the South, by the Bright of Biafra: in the east, by the Republic of Cameroon: in the north, by the south-east geo-political zone: and in the south-west, by the south-west geo-political zone. The term Niger Delta province was first used by Franki and Cordry at the 7th World Petroleum Conference 1967 to describe the Niger Delta region as a region South ward from Onitsha, Benin and Umuahia where oil and gas were found in commercial quantities. ${ }^{3}$ However, for our present purpose, Niger Delta region refers to the region of Nigeria which comprises of the whole of South-South geo-political zone consisting of Edo, Delta, Bayelsa, Rivers, Akwa-Ibom and Cross-River state.

To an extent, it also includes parts of south-east geo-political zone and south-west geo-political zone particularly, Abia, Imo, and Ondo state respectively. The Niger Delta region is one of the richest regions in Nigeria in particular and the world in general. The region in term of its mineral resources, is at par with other delta regions of the world such as the Amazon in Brazil, Orinoco in Bangladesh and the Mekong in Vietnam, ${ }^{4}$ just to mention but a few.

The Niger Delta region has one identified petroleum system known as tertiary Niger Delta which is about 34.8 trillion cubic feet's of gas reserves. According to the United States Geological Survey, Central Energy Resources Team of the United States Department of States, most of the petroleum deposits in the region are in fields i.e on shore and off shore in the continental sheet waters that are less are less than 200 meters deep. They

\footnotetext{
${ }^{1}$ See, section 175(1)(a) Constitution, Federal Republic of Nigeria, 1999, as amended in 2011.

${ }^{2}$ Section 175 (1)(c), ibid.

${ }^{3}$ L. Michael, W. Tuttle, R.R. Charpentier and M.E. Brown Field, “The Niger Delta Petroleum System: Niger-Delta Province, Nigeria, Cameroun", United States Geological Survey Chapter II.

${ }^{4}$ Ibid.
} 
are primarily found in simple structure. ${ }^{1}$

Undoubtedly, there is a special geographical location in Nigeria refers to as Niger Delta. The region has a particular terrain and a peculiar development needs, but identifying the component ethnic makeup, in term of its indigenous communities can be problematic if not difficult. This is also true of the linguistic ethnographic and cultural identity of the people of the region.

However, among the bewildering indigenous communities of the Niger Delta region, one can easily identify the Edo's, Ijaw's, Ogonis, Itsekins, Urhobos, Ikwerres, Ibibios, Annangs, Ifiks, Opobos, Kalabaris and Delta Ibos. The people of the Niger Delta, like other ethnic nationalities in Nigeria are culturally diverse and historically different in their political behaviors. This is possibly as a result of individual communities' peculiar riverine geography which isolates settlements on the little available dry land, surrounded by maze of creeks which fostered small but active ancient city states and kingdoms such as Bonny, Brass, Akassa, Okrika, Nembe, Ogoni, Opobo, Andoni and Itsekiri.

According to Tamuno, ${ }^{2}$ the Niger Delta region of Nigeria comprised about $70,000 \mathrm{sq} \mathrm{km}$. this is in contrast to the World Bank Technical Report 1995, which put the total land mass of the region at about 20,000 sq. km. In order to appreciate the needs of the people of the region and develop it; it is important we stress that the region, as the resource base of the nation, have its peculiar needs which a faithful adherence and implementation of the provisions of Chapter II of the Constitution, Federal Republic of Nigeria, 1999 (as amended) would have solved to an extent.

Unfortunately, the lofty political, ${ }^{3}$ economic, ${ }^{4}$ social,${ }^{5}$ educational ${ }^{6}$ and environmental ${ }^{7}$ objectives which should have acted as fundamental objectives that directs state policies were not whole heartedly adhered to. That neglect snow balled into militant activities that engulf the region before the proclamation of the Niger Delta Amnesty.

\section{Militancy and the Proclamation of the Niger Delta Amnesty}

Undoubtedly, the militants' activities in the Niger Delta and the consequential acts of impunities which resulted in the loss of several lives and properties was a serious draw back on the needs of the people of the region and its development. According to Akwem and Dever,

The grave implication of the continued conflicts in the Niger Delta maybe appreciated against the background of the fact that from historical experience, the Nigerian nation and especially, the Niger Delta have had a prolonged familiarity with social struggle against colonial rule, The Niger Delta militants are drawing from this experience in prosecuting the current phase of the confrontation with the Nigerian state. Like the struggle against colonialism, the present phase of crises has incubated over long periods of unaddressed grievances and disenchantments among communities in the region. ${ }^{8}$

In the words of Biakpara:

What the people of Delta are asking for is equity and justice, and due recognition of their rights as citizens. These issues are contained in the Kiama Declaration and similar declarations by other groups in Niger Delta. i.e. The people are insisting on a cessation of the destructive oil explorative activities which destroys the Niger Delta ecology and human lives. ${ }^{9}$

Amplifying the above contention, Mamka advised that:

The situation in the Niger Delta is both curious and it is annoying paradox. The people live in difficult coastal areas surrounded by water and yet, do not have enough water to drink. Their creeks are littered with pipelines bearing petroleum products to another part of the country: but in Niger Delta, fuel is scarce and expensive. For example, fuel is costlier in Yenogoa than in Kano. The Niger Delta have commented that before their very eyes, revenue from crude oil sales is taken away to provide infrastructure in other parts of the country (beautiful roads in Abuja, skyscrapers and flyovers in Lagos etc) while many communities in the Niger Delta are Cut-off from civilization because there are insufficient roads or bridges to get them. ${ }^{10}$

\footnotetext{
${ }^{1}$ L. Michael, W. Tuttle, R.R. Charpentier and M.E. Brown Field, "The Niger Delta Petroleum System: Niger-Delta Province, Nigeria, Cameroun", United States Geological Survey Chapter II.

${ }^{2}$ See section 15, Constitution of Federal Republic of Nigeria, 1999 as (amended 2011).

${ }^{3}$ Section 15 , ibid.

${ }^{4}$ Section 16 , ibid.

5 Section 17 , ibid.

${ }^{6}$ Section 18 , ibid.

${ }^{7}$ Section 20, ibid.

${ }^{8}$ S.W. Peters Op. cit

${ }^{9}$ Y.P. Biakpara, "The Niger Delta Question: Critical Challenges of Development and Democracy", Being a paper presented at The Annual General Summit of Ijaw Youths, held on $10^{\text {th }}$ August 2010 at Yenogoa, Bayelsa State.

${ }^{10}$ Y.P Biakpara and Mamka, "General Comments on Niger Delta Question", Being a joint paper presented at the Annual Ijaws Youths Summit, held on $10^{\text {th }}$ August 2020 at Yenogoa, Bayelsa State.
} 
The Willinck Report, 1958 and the World Conference on Environment and Development 1978 showed that neglect, extensive environmental degradation and lack of social amenities are at the heart of the agitation in the Niger Delta region. Overtime, a new breed of violent agitators (militants) arose from the hitherto non-violent agitation founded on a valid claim of neglect of the people of the region by successive Federal Government of Nigeria. The makeup of this new breed of violent agitators are groups such as Niger Delta Volunteer Forces (NDVF), Movement for the Emancipation of the Niger Delta (MEND) etc. The modus operandi of these new breed of violent agitators referred to as militants, were in sharp constrast to that of the largely, non-violent, Movement for the Survival of the Ogoni People (MOSOP) led by the irrepressible, late Ken Saro-Wiwa.

The violent take off of the agitation by militant groups of the Niger Delta region for equitable distribution of "their resources" ushered Nigeria into a dark period of violent agitations where anarchy and impunity reigned supreme. Within that period, act of criminalities such as kidnapping, rape, murder, ransom taking, oil bunkering, pipeline and vandilisation of oil facilities or installations were common place. The unprecedented number of acts of impunity that was the order of the day, increased the difficulties the people of the region faced. These act of impunities or criminalities by militants of the region were met with stick and carrot counter measures of the Federal Government of Nigeria. ${ }^{1}$ Sadly, the counter measures did not succeed.

In fact, the crisis in the region, rose to a new height when a group of militants gruesomely murdered five policemen sent to a sleepy Niger Delta town of Odi, ostensibly, to effect the arrest of some militants accused of terrorist activities. As a result of the afore-stated murder, the then President of Nigeria, Chief Olusegun Obasanjo directed the then Governor of Bayelsa State, ${ }^{2}$ D.S.P Alamesiegha, (being the Chief Security Officer of Bayelsa State), to identify, apprehend and handover the accused persons to the Federal Government of Nigeria. ${ }^{3}$

It is important to note that ordinarily, such a presidential directive should have been properly routed through the Inspector General of Police to the Commissioner of Police, Bayelsa state and not the governor of the state. ${ }^{4}$ In any case, the Governor failed to do so; and the President, acting as the Commander-in-Chief of Nigeria armed forces, ${ }^{5}$ deployed an expedition troop to Odi town to arrest or liquidate the perpetrators of the alleged crime. Unfortunately, the aftermath of the expedition showed several losses of lives and destruction of properties of the inhabitant of the town. Ironically, none of the accused militants were arrested or killed.

In the words of a former President of Nigeria, Good luck Jonathan: "...If bombarding Odi was to solve the problems (of militancy), it never did. Rather we saw dead people, mainly old men and women and also children. None of the militants was killed". 6

No words captured the Niger Delta crisis (caused by militancy) better than the graphic description of the situation as painted by Reuben Abati. According to him:

They attack (i.e. militants), oil installation, kidnapping oil company officials, seeing that crude oil is stolen openly by state officials and that a whole ship bearing oil cargo can disappear from Nigerian shores and the Navy and everyone else could claim ignorance. The militants have also began to engage in illegal oil bunkering. ${ }^{7}$

According to Itse Sagay, the alarming activities of militants in the Niger-Delta region reached such proportion and instractable form because of the sustained oppression and gross neglect of the region that produces the highest revenue for the nation. ${ }^{8}$ In order not to allow militants to hijack the genuine efforts of the Niger-Delta region for a just redistribution of her natural resources, the political leaders of the region organized a retreat for south-south geo-political zone. In that retreat, they condemned the attacks on oil and other business activities which has made the region unsafe for legitimate business activities to thrive while canvassing for sustained campaign and struggle to reverse the prevalent injustice against the people of the region, which prevented them from enjoying their God given resources. ${ }^{9}$

The desperation in the Niger-Delta that led to the militancy is due to lack of aspiration among the people of the region due to failed govern policies and programmes. The persistent and prevelent nature of the violence caused by the militant's activities and the counter measure employed by the government of Nigeria to curb the crisis was a source of worry to the international community. Hence, the mediatory role of the Amnesty International in the Niger-Delta crisis.

The organization, in its mediatory role, recommended that, Nigeria, as a matter of urgency and public

\footnotetext{
${ }^{1}$ For Example, the establishment of the oil minerals producing Areas Development Commission (OMPDEC) Decree No23 of 1992 (now repealed). That institution was later reconstructed as the Niger Delta Development Commission (NDDC) Act No. 6 of 2000.

${ }^{2}$ Odi town is in Bayelsa State.

${ }^{3}$ See section 176(2) of the 1999 Constitution of Nigeria, (as amended in 20111).

${ }^{4}$ See sections 4 and 10(2), Police Act Cap. 19 Laws of the Federation of Nigeria 2004

${ }^{5}$ See section 130(2), Constitution of Federal Republic of Nigeria, 1999 (as amended in 2011).

6 "Jonathan under Attack". News Magazine, $20^{\text {th }}$ November 2012. https://www.newsorg visited on 25/5/2013.

${ }^{7}$ Quoted in "Opinion on Niger Delta Militants. General Comments", Being a paper presented by Y.P Biakpara at the Annual Youth Ijaw Youths Summit held on $10^{\text {th }}$ August 2010 at Yenegoa, Bayelsa State

${ }^{8}$ See News Watch Maganize, $21^{\text {st }}$ August 2008, p.16. See also http://www.newswatchonline.org.com, visited 15/12/2015.

9 "South - South Legislative Retreat: Focus on the Militancy in the Delta", vanguardonline.com visited 21/11/2015.
} 
importance, should devise a programme which would ensure the implementation of the United Nations "Principles for the Protection and Promotion of Human Rights through Action"1 and address the age long neglect of the people of the region and its environmental degradation.

In order to end militant's activities in the region, the federal government committed herself to the clean-up of oil spillage, address neglect of the people, and the granting of amnesty to the militants of the region.

Consequent on that, the federal government of Nigeria, under the leadership of Late President Umara Musa Yar'adua set up a Presidential Technical Committee on the Niger-Delta. This was when it down on the federal government that its military counter measures cannot solve the Niger-Delta crisis.

In the words of the former President of Nigeria, "If the attacks (by government) had solved the issue of militancy in the Niger-Delta, the Yar'adua Government which I had the privilege of being the Vice President would have not come up with the amnesty". ${ }^{2}$ The Presidential Technical Committee on the Niger-Delta recommended two approach to the Niger Delta Amnesty Programme. First is demobilization and disarment of the militants and second, the amnesty programme of reprieve (pardon) and rehabilitation. The granting of amnesty and rehabilitation of ex-militants is on the condition that they agree to be demobilized and disarmed. ${ }^{3}$ The President accepted the recommendations and declared the commencement of the Niger-Delta Amnesty programme on $6^{\text {th }}$ August, 2009

\section{The Nature of Amnesty and Executive Order}

\subsection{What is an Amnesty?}

The idea that a Sovereign State can officially grant amnesty to a group (class) of persons who are subject to trial but have not yet been tried or convicted is, as old, as the rise of nation-states. However, amnesty in its modern understanding, is traceable to the Greek word, "amnestia" which in English means, forgetting. The history of amnesty (amnestia) dates back to $403 \mathrm{BC}$ when a protracted civil war between Athenians ended with the victorious faction, as the emerged government granted amnesty to the vanquished based on "Oath of Loyalty" to the sovereign. That proclaimed amnesty was officially known as "Act of Oblivion" which was later enacted as a law that specifically prevented the prosecution of those perceived to be political enemies as a result of that war.

Amnesty which also means, pardon, has over the years, evolved from its original meaning and acquired a distinct meaning in constitutional law and principle of international law. Nowadays, Amnesty (pardon) is used as a measure of more general nature directed to offences whose criminality, though serious, is considered better forgotten than punished.ie political offence.

However, political offence that can be pardoned or amnestized must not be acts of genocide, war crime, crime against humanity, or other similar grievous crimes. This is because article 5,6,7, and 8 of the Statute of Rome which established the International Criminal Court prohibits grant of amnesty to anyone or group accused of committing any of the heirious crimes stated above. ${ }^{4}$ For example, in Gomez v. Brazil ${ }^{5}$ The Inter-American Court of Human Rights considered the case of a group of students and workers that allegedly disappeared under the watch of some elements of the Brazilian army and state police in the 70s. Though, the Brazilian Amnesty Law prevented the release of information on the fate of the victims or the investigation and prosecution of those behind their disappearance, the Inter-American Court of Human Rights held that the investigation, prosecution and punishment of the people behind the disappearance is necessary for justice for the victim and that amnesty granted to those behind the disappearance is against international convention which Brazil is a state party.

Similarly, in The Prosecutor v. Issa Hassan Sesay, Morris Kallon \& Anor, ${ }^{6}$ the Appeal Chambers of the Special Court for Sierra Leone ruled that the amnesty granted to the three accused person of the warning faction in Sierra Leone, based on the Lomé Peace Accord (LPA) between the government and the Revolutionary United Front (RUF) was not a bar to their prosecution. This is because: that amnesty did not apply to war crimes and other crimes that constitutes a violation of international humanitarian law.

Amnesty being a reprieve extended by the government to a group (class) of persons usually for political offence $(s)^{7}$ is of two types - specific pardon and general pardon. A specific pardon is a reprieve of a particular kind i.e. criminal reprieve granted by the government to a person or an individual. An amnesty granted by the government to a group (class)of person is usually referred to as general pardon i.e. granted to political offenders. ${ }^{8}$ This pardon generally free the beneficiaries of the pardon from conviction and punishment. In Burt v. Governor

\footnotetext{
${ }^{1}$ UNDOC “Combating Impunity" Vol. I 2005 undocumentonline.com Impunity visited on 3 rd/1/2006.

${ }^{2}$ See, "Jonathan under Attack" News Magazine $20^{\text {th }}$ November 2012. http://www.news.org visited on 25/5/2013.

${ }^{3}$ See Ukoha, "Trimming and Sequencing in Peace Building: The Case of Nigerians Niger Delta Amnesty Programme", Centre for Research on Peace and Development (CRPD), Working Paper No 36, 2015, 3.

${ }^{4}$ See also "The United Nations Study on Amnesty and their Roles in the Safeguard and Promotion of Human Rights" UNDOC E/CN 4 Sub $21285.164 .20 \mathrm{~d} /$ at 8

${ }^{5}$ Report 71/15/ CASE 12,879.

${ }^{6}$ Case No SCSL -04-15-7.

${ }^{7}$ B.E. West, Encyclopedia of American Law, $2^{\text {nd }}$ Edition Vol.12 (2008), 106.

${ }^{8}$ See Leslie Sebba, “Amnesty and Pardon”, Encyclopaedia of Crime and Justice 1983, 59.
} 
General, New Zealand, ${ }^{1}$ a New Zealand court described general pardon as discretionary but sometimes arbitrary use of His majesty right of grace in pardoning offenders.

A specific pardon or general pardon maybe free of condition or subject to condition like the specific pardon provided in section175(1)(a) - (d) of the Constitution, Federal Republic of Nigeria,1999 as amended in 2011. Amnesty whether specific or general are of two kinds - express and implied amnesty. An express amnesty is granted in direct terms while implied amnesty is granted indirectly i.e. from a peace treaty executed between the contending parties. Whether express or implied, amnesty can also be for a stated period of time during which the beneficiaries are not prosecuted and/ or punished for committing a crime. For example, the Hungarian amnesty granted to mark the celebration of the year of the child was for stated period of time. That amnesty was based of the national guide to prevent excessive use of force by police officers within a stated time. That is the period some children in Hungary were forcefully separated from their families and detained by police.

Similarly, in Argentina, before the dawn of civil rule, the ongoing military government or regime promulgated an amnesty decree called "The Pacification Law" which obviated any possibility of criminal and /or civil liability against beneficiaries of the law accused of committing serious crimes during the time of attempting to restore public order in Argentina.

Amnesty or pardon of whatever type can be granted by the executive or legislative branch of government depending on the provision of the national constitution. For example, section 175(1)(a) - (d) of the Constitution, Federal Republic of Nigeria confers on the President of Nigeria prerogative of mercy.

Similarly, article 118 of the Constitution of Haiti, 2012 provided that the President of Haiti can grant amnesty for political offences in accordance with the law. Article 73(7) of the Constitution of Japan, 1947 confers power on the Japanese Parliamentary Cabinet to determine and grant general pardon or specific pardon commuting of punishment (clemency). It also conferred on the Parliamentary Cabinet the power to grant other forms of reprieve and restoration of rights. In the same vein, article 29 of the Constitution of Iceland, 2010 confers on the President, the power to decide whether to withdraw prosecution of anybody if there are cogent reasons to do so.

Since the precedent established by the Greek "Act of Oblivion" which granted general pardon (amnesty) to some political offenders, and exempted them from prosecution and/or conviction, most general pardons, in modern time, are directed to offences whose criminality, though serious, is considered better forgotten them prosecuted and/or punished.-This is however subject to the provisions of the United Nations Convention on the Non. Application of Statutory Limitation to War Crimes and Crimes against Humanities, 1968 and its Additional Protocols that limits the extent to which general pardon (amnesty) can be granted. ${ }^{2}$

\subsection{What is an Executive Order?}

Executive order is a means of using federal directive in order to manage the operation of the federal government. The first exercise of Executive Order occurred in the United States when President George Washington granted amnesty in 1795 to participants in the "Whiskey Rebellion", which was a tax protest against an unpopular exercise tax. The rebellion occurred between 1791-1794 in Western Pennsylvania under the command of American revolutionary war veteran, Major James Macfarlane. It only ended as a result of the conditional amnesty based on an Executive Order granted by President George Washington which allowed the United States government to forget the crimes of those involved in exchange of their signature on oath of loyalty to the United States.

However, the most famous exercise of Executive Order was the "Proclamation of Emancipation" issued by President Abraham Lincoln of the United States on $1^{\text {st }}$ January 1863. That proclamation (95) granted to slaves emancipation (freedom) on the condition that the confederate states fails to return to the union by $1^{\text {st }}$ January 1863 and the unionists win the war.

The legal legitimacy of the exercise of Executive order by the president in the United States lies on article2(2) of the Constitution of the United States $1776\left(8^{\text {th }}\right.$ Amendment $)$ which provides that the President shall have powers to grant reprieve or pardons for offences against United States, except in impeachment cases. In Nigeria, the power of the President to exercise Executive Order stems from the provision of section 130(2) of the Constitution Federal Republic of Nigeria, 1999 (as amended in 2011) which confers on the President the status of Chief Executive Officer of the Federation and Commander- in - Chief of the armed forces. That constitutional provision grants him implied authority to issue federal directive (Executive Order) in furtherance of his constitutional power. ${ }^{3} \mathrm{He}$ can exercise that implied power directly or indirectly through the vice President or ministers of the government of the Federation or officers in the public service of the federation. ${ }^{4}$ The power of the President of Nigeria to issue federal directives (Executive Order) directly or indirectly extends to the execution and maintenance of the provisions of the constitution, laws enacted by the National Assembly and all matters incidental to it which the National

\footnotetext{
${ }^{1}$ (1993), 3 NZLR 672 at 681.

2 See United Nations Resolution 1391, Dated $26^{\text {th }}$ January 1968.

${ }^{3}$ See section 130(2) Constitution of Federal Republic of Nigeria (as amended) in 2011.

${ }^{4}$ Section 5 (1)(a), ibid.
} 
Assembly has power to make law. ${ }^{1}$

Years after the exercise of Executive Order (No 95) by President Abraham Lincoln which proclaimed emancipation (freedom) for American slaves in 1863, successive Presidents of the United States have been generally mindful in citing the specific law under which they act whenever they issue new Executive Order. Thus, when a United States President believes that his authority to issue Executive Order stems from a particular law, that law and its provision is usually stated in the Executive Order. For example, "Under the authority vested in me by section.... of the Constitution" or "Section.... of... Act of the Congress of the United States".

The above practice has acquired the status of a convention and has led to the emergence of numbered Executive Order i.e. Executive Order 10340 issued by President Henry Truman which placed all steel mills in the United States under the control of the Federal Government.

\section{The Niger Delta Amnesty and the Question of Legal Legitimacy}

It is well over a decade since the former president of Nigeria, now late, President Umaru Musa Yar'adua proclaimed the Niger Delta Amnesty on $6^{\text {th }}$ August 2009. Definitely, a decade plus is enough to take stock of the legal legitimacy of that action; especially now that one can rightly assume, to an extent, that the initial euphoria generated by that important public proclamation has died down.

There is an old Idoma saying which says: "In a matter of heart, ask the face". ${ }^{2}$ And so, In the matter of the legal legitimacy of the proclamation of the Niger Delta Amnesty by the President, we shall search the law. However, let me pre-empt our search by stating categorically that, that amnesty suffers three serious crises of legal legitimacy. They are:

\subsection{Lack of Constitutionality on Prerogative of Mercy}

The proclamation of the Niger Delta Amnesty is not in accordance with the provisions of sections 175(1) (a)-(d) and 64(1) - (3) of the Constitution, Federal Republic of Nigeria 19993 which provides for the president's power of prerogative of mercy and proclamation respectively. Section 175(1) (a)-(d) of the extant constitution which confers on the President the power to exercise prerogative of mercy specifically delegates that power to him in the following words:

1) The President may-

a) Grant any person concerned with or convicted of any offence created by an Act of the National Assembly a pardon, either free or subject to lawful conditions.

b) Grant to any person a respite, either for an indefinite or for a specified period of the execution of any punishment imposed on that person for such an offence.

c) Substitute a less severe form of punishment imposed on that person for such an offence. or;

d) Remit the whole or any part of the punishment imposed on that person for such an offence or for any penalty or forfeiture otherwise due to the state on account of such an offence.

In Amanchukwu v. FRN (No. 2), ${ }^{4}$ the Court of Appeal per Udo Azogu JCA (as he then was) restated the President's power to grant pardon (amnesty) under any of the circumstances listed in section 175(1) (a)---(d). The same court pronounced on the constitutional power of the President to grant pardon (amnesty) under any of the circumstances listed on the section 175(1)(a) - (d) in the case of Falae v. Obasanjo \& Ors. (No. 2). ${ }^{5}$ According to the words of Musdapher JCA (as he then was) in the aforementioned case:

In Exhibit II, the Head of State (President) granted Rtd. General Olusegun (Obansanjo) pardon.

The word used is pardon and or without conditions. It is clean from exhibit II that the pardon

granted to the $1^{\text {st }}$ respondent (Olusegun) was not made subject to conditions. ${ }^{6}$

A pardon (amnesty) under section 175 (1) (a)_(d) of the extant constitution of Nigeria is an act of grace by the President which obviates or mitigates the offence and restores the rights and privileges forfeited on account of the offence. ${ }^{7}$ In order to understand that the grace of pardon granted to Niger Delta militants in 2009 is not in accordance with the provision of section 175 (1)(a) - (d) of the afore stated section of the constitution contemplates pardon for an individual (person) and not group(class) of persons. Hence, the reference to "any person", "that person" or the persistence use of singular word to represent the intended beneficiary of the pardon the president can grant under section 175(1) (a)-(b). Second, the provision of the section only envisages specific pardon that can be granted to a person and not a general pardon that can be granted to a group (class) of persons. Therefore, from the general tenor of section 175 (1)(a) - (b), pardon in the form of prerogative of mercy can be granted only to a

\footnotetext{
${ }^{1}$ Section $5(1)(\mathrm{b})$, ibid.

${ }^{2}$ Idoma is an ethnic group in Nigeria. They can be found in the middle belt region of Nigeria also called North-Central geo-political zone of Nigeria.

${ }^{3}$ As amended in 2011.

${ }^{4}$ (1999) 4 NWLR (Pt. 599) 479 at 479.

5 (1999) 4 NWLR (Pt. 599) 721.

${ }^{6}$ Ibid, 721 .

${ }^{7}$ Ibid, 295.
} 
person concerned with the offence, that is, the individual accused of a crime or convicted of a crime created by an Act of the National Assembly.

Essentially, such a person or an individual must be concerned or convicted of an offence created by the Act of the National Assembly and not merely accused of a crime or concerned with any offence created by an Act of the National Assembly. This is because; a mere suspicion or accusation or even a link to a crime does not amount to conviction since it is a settled law that an accused person is presumed innocent until the contrary is proved. Thus, conviction must precede pardon in any valid amnesty.

Hence, the Supreme Court advised in Monsura Solola Anor. v. The state ${ }^{1}$ that:

It needs to be stressed for future guidance that a person convicted for murder and sentence to death by a High Court and whose appeal is dismissed by the Court of Appeal and a further appeal is made in the Supreme Court, until his appeal is finally determined, the Head of State(President) or governor pursuant to section 175(1) or 212 of the 1999 Constitution cannot exercise power of prerogative of mercy in favor of the person and in the same vein, such a person cannot be executed before his appeal is disposed of. It is hope that persons in authorities will be guided by the advice.

Thus, a beneficiary of the President's exercise of prerogative of mercy must be investigated, tried and convicted by a competent criminal court based on an offence created by an Act of the National Assembly before such a person can be pardoned under section 175 (1) (a)--- (d). This was the opinion of the court in Olarewaju $v$. Afribank Plc. ${ }^{2}$

Since none of the Niger Delta militants has been convicted of any offence created by an Act of the National Assembly, they cannot, even individually, be granted amnesty or specific pardon by the President under section 175(1)(a) of the constitution. Moreover, since none of the militants has had a respite, "either for an indefinite or for a specified period" in respect of the execution of any punishment imposed on him or her for such offence, none of them can be granted amnesty. Furthermore, since none of them has had his or her punishment substituted for a less severe form of punishment or had a remittance of the whole or any part of any punishment imposed on him or her for such an offence or forfeiture due to the federal government on account of such an offence, a pardon (amnesty) cannot be granted under section 175(1)(c) - (d) of the constitution. All these shows that the Niger Delta Amnesty was not granted in accordance with section 175(1) (a)-(d) of the constitution. ${ }^{3}$

\subsection{Non-Compliance with Issuance of Proclamation by President}

Another constitutional defect of the Niger Delta Amnesty is its noncompliance with the issuance of power of proclamation granted to the president by section 64 of the Constitution. That section of the current constitution of Nigeria empowers the President to by a proclamation:

a) Extend the period to hold election to the National Assembly if the federation is at war in which the territory of Nigeria is physically involved and the President considers that it is not possible or practicable to hold election. ${ }^{4}$

b) Issue a proclamation for the holding of the first session of the National Assembly immediately after his being sworn in or for its dissolution. ${ }^{5}$

Since the grant of the Niger Delta Amnesty by the President do not relate to any of the issues under section 64 (2) and (3) of the constitution, the proclamation of the Niger Delta Amnesty is not in accordance with his exercise of power of proclamation.

\subsection{Not in Accordance with an Act of the National Assembly}

The granting of the Niger Delta Amnesty is not in accordance with any Act of the National Assembly. This is fatal because; the assumed executive power of the President as encapsulated in section 5 of the constitution is to execute and maintain the constitution, all laws made by the National Assembly and all matters with respect to which the National Assembly has for the time being power to make laws.

Granted that the Niger Delta Amnesty was predicted a matter which the National Assembly have power to legislate on, failure on the part of the executive to ensure that the National Assembly passed the Niger Delta Amnesty Program into law before its' proclamation by the president, is a serious lapse which greatly challenge the legal legitimacy of the amnesty granted to the Niger Delta militants by the president. ${ }^{6}$

As it stands now, the Niger Delta Amnesty lacks legal legitimacy. Perhaps, one can say; for the sake of credibility that its only claim to legitimacy is the fact that it is founded on the exercise of a judicial power by the

\footnotetext{
${ }^{1}$ (2005) NSQCR (vol. 1); (2007), NWLR (Pt. 1029) at 24.

2 (2011) 7 NSCQR 22.

${ }^{3}$ See section 36(4), Constitution Federal Republic of Nigeria, 2011 as amended

${ }^{4}$ Section 64(2), ibid.

${ }^{5}$ Section 64(3), ibid.

${ }^{6}$ Section 5(1)(b). ibid
} 
president in form of an Executive Order. Of course, the complexities of modern governance have necessitated the need for the executive branch of government to have executive power in order to discharge its constitutionally allocated powers. As the only branch of government that works day to day, the need to invest it with Executive Order in order to further its functions cannot be over emphasized. This is because; the exercise of judicial or legislative power by the executive branch, through the instrument of Executive Order ensures that government policies and programmes are carried out expeditiously.

However, like every exercise of judicial powers or legislative power, the administrative directive carried out through executive order, must be in accordance with the intention or tenor of the enabling or implied Act of the National Assembly. Thus, where a delegated, broad or implied power of the President is applied wrongly, that exercise will be held as an ultra vires act of the executive head.

In Youngstown Sheet \& Tube Co. $v$ Sawyer, ${ }^{1}$ a United States court judicially reviewed the exercise of Executive Order 10340 issued by United States President Harry Truman wherein he placed all steel mills in the country under federal control. The court held that the President acted ultra-vires because; he attempted, by that order to make a law rather than clarify or further an act enacted by the Congress or enshrined in the constitution of United States.

Granted that the proclamation of the Niger Delta Amnesty by the President was a valid exercise of Executive Order which was carried out in furtherance of his broad power as the Chief Executive of the Federation that does not erase the necessity of enacting the same as an Act of the National Assembly for its legal effectiveness. Hence, the President as a matter of public importance and urgency is required to package the Niger Delta Amnesty programme, as an Executive Bill to the National Assembly to be enacted as an Act of the National Assembly.

First, doing so will guarantee the longevity of the amnesty, isolate it from political meddling and its use as a political tool. Second, enacting the amnesty into an Act of the National Assembly will secure its alternation by succeeding president or any of his official acting according to his directive or in his name. This point is important because an Executive order, though not a law, remain enforce until cancelled, revoked, adjudged unlawful or expired on its term. Hence, an incumbent President or any of his successors can, at any time, revoke, modify or make exceptions to any Executive Order; whether or not the order was made, issued or signed by the current president or official acting in his name.

\section{Recommendations}

Good thought does not necessary translate to good deed but the assurance of what good a law can do still holds way in the mind of men. Hence, the recommendation that as a matter public importance and urgency, the Executive Order that birthed the Niger Delta Amnesty should be package as an Executive Bill to the National Assembly for enactment into law. This will shade it from undue political influence and envelope it with the much needed legal legitimacy. For example, Executive Order 9066 issued by United States President, Theodore Roosevelt which desegregated military zone and Executive Order 9981 issued by United State President, Harry Truman on $1^{\text {st }}$ July 1948 Which desegregated the United States armed forces were later on enacted as Acts of the United States Congress.

\section{Conclusion}

The Niger Delta Amnesty is what it is - a policy prescription may, a federal directive founded on Executive Order. It does not form part of the constitution or Act of the National Assembly; neither can it claim parity with any of them. Hence, it has no claim to legal legitimacy. At best, one can ascribe a mere quasi-judicial legitimacy to it, or recognize it as a programme that is socially and politically important to the unity and survival of corporate Nigeria.

\section{References}

Biakpara, Y.P. and Mamka, B. (2020), "General Comments on Niger Delta Question”, Being a joint paper presented at the Annual Ijaws Youths Summit, held on $10^{\text {th }}$ August 2020 at Yenogoa, Bayelsa State.

Biakpara, Y.P., "The Niger Delta Question: Critical Challenges of Development and Democracy”, (2010), Being a paper presented at The Annual General Summit of Ijaw Youths, held on $10^{\text {th }}$ August 2010 at Yenogoa, Bayelsa State.

Leslie Sebba, “Amnesty and Pardon”, Encyclopaedia of Crime and Justice 1983.

Michael, L., Tuttle, W., Charpentier, R.R. and Brown Field, M.E. (2005), "The Niger Delta Petroleum System: Niger-Delta Province, Nigeria, Cameroun", United States Geological Survey Chapter II.

See Ukoha, H. (2015), "Trimming and Sequencing in Peace Building: The Case of Nigerians Niger Delta Amnesty Programme”, Centre for Research on Peace and Development (CRPD), Working Paper No 36 , 2015.

United Nations, "Study on Amnesty and their Roles in the Safeguard and Promotion of Human Rights" UNDOC

\footnotetext{
1343 US 579.
} 
E/CN 4 Sub 21285. 164.20d/8.

West, B.E., Encyclopedia of American Law, $2^{\text {nd }}$ Edition Vol.12 (2008).

Amanchukwu v. FRN (No. 2), (1999) 4 NWLR (pt. 599) 479 at 479.

Burt v. Governor General, New Zealand, (1993), 3 NZLR 672 at 681.

Falae v. Obasanjo \& Ors. (No. 2). (1999) 4 NWLR (pt. 599) 721.

Gomez v. Brazil Report 71/15/ CASE 12,879.

Monsura Solola Anor. v. The state (2007), NWLR (Pt. 1029) at 24.

Olarewaju v. Afribank Plc. (2011) 7 NSCQR 22.

The Prosecutor v. Issa Hassan Sesay, Morris Kallon \& Anor. Case No SCSL -04-15-7.

Youngstown Sheet \& Tube Co. v Sawyer, 343 US 579. 